\title{
Systemic Genesis Approach in Psychology
}

\author{
Galina Suvorova \\ Moscow State Pedagogical University

\begin{abstract}
Correspondence concerning this article should be addressed to Galina Suvorova, Department of Psychology, Moscow State Pedagogical University, M. Pirogovskaya st., 1, b. 1, Moscow, Russian Federation, 119607.Email: suvorovaga@mail.ru
\end{abstract} \\ Tatyana Baranovskaya \\ National Research University Higher School of Economics

\begin{abstract}
Correspondence concerning this article should be addressed to Tatiana Baranovskaya, National Research University Higher School of Economics, Malaya Pionerskaya, 12, Moscow, Russian Federation, 115054.E-mail: tbaranovskaya@hse.ru
\end{abstract}

\begin{abstract}
This article analyses V.D. Shadrikov's scientific work in the field of psychology. V.D. Shadrikov is Doctor of Psychology, Professor, and Fellow of the Russian Academy of Education. The article briefly covers his fundamental publications on activity, abilities, and the human inner world, examining the issues raised in his publications in the context of the evolution of educational theory and methodology. Shadrikov develops the methodology of systemic genesis approach in psychology, demonstrating that the systemic genesis paradigm opens new aspects in fundamental and applied psychology. This paradigm provides an opportunity to carry out research on a new level.
\end{abstract}

Keywords: systemic genesis, activity, abilities, human inner world, development, teaching, education

“... Nowadays special conditions for the development of systemic genesis approach both in fundamental psychology and in applied psychology are realized..."

V. D. Shadrikov, 1976

\section{Systemic Genesis Paradigm as a New Development Stage of System Approach in Psychology: Headnote}

The systemic genesis approach contributes to the $21^{\text {st }}$ century focus on methodological and conceptual problems in the discipline of psychology. It works out the conceptual framework, offering a description and clarification of psyche, laying down the laws of mental functioning and analyzing developmental trends in psychology.

Based on the conceptual framework provided by system theory, systemic psychology considers the ongoing interaction among human beings as a privileged object of psychological analysis and is, therefore, essentially focused on interpersonal systems. Systemic psychology has allowed further development of the interpersonal features of human behavior that psychological disciplines focused on in the latetwentieth century and its domain is defined by the stress placed on interactive and communicative processes taking place among the members of an interpersonal system. Moreover, a systemic genesis approach provides for an integration of these processes with the intrapsychic dynamics and the personal history of the individual. Methodologically speaking, the systemic genesis paradigm can be largely applied to all human interactive systems.

Vladimir Dmitriyevich Shadrikov has become the founder of much research and theory in the systemic genesis branch of psychology. Born in 1939, he is a prominent Russian scientist, methodologist of Russian psychology, Doctor of Psychology (1977), Professor (1978), Corresponding Fellow of the Academy of 
Pedagogic Sciences of the USSR (1982), Fellow of the Russian Academy of Education (1992), and is wellknown to all those concerned with psychological issues and pedagogical practices in education. In the field of fundamental and theoretical psychology, he is a conspicuous researcher of human activity and abilities. He has created new, path-breaking trends of study and shown their deep intrinsic relation with methodological problems in human developmental psychology, professional training and learning. Shadrikov's theories offer concepts for resolving some theoretical problems in psychology and practical challenges facing it in different spheres of life in contemporary Russian society. He also lays down regulations, emphasizes new strategies in cognition and understanding of mental world.

He has worked out a strict conceptual framework to describe mental law, human activity and abilities. He has also identified methodological principles and theoretical procedures for a systemic analysis of psyche as a complex object of cognition. Shadrikov has made a great contribution in the development of a system of psychological knowledge of fundamental psychological problems (Suvorova, 2007).

\section{Methodological and Theoretical Issues of Psychology in the Works of V. D. Shadrikov: System Genesis Aspect}

Systemic genesis paradigm is oriented towards interpersonal systems, focusing its intervention on the interactive and communicative features of human behavior. So defined, this theory and practice is applicable to every interactive human system, although psyche is traditionally the primary and privileged field of study and application to the point of using the restrictive definition of systemic-relationship paradigm.

The system genesis approach has been elaborated in works by Shadrikov and his pupils from 1976 to the present day (Shadrikov, 1994; 1998; 1977; 2007; 2006; 2009; 2007; 2001; 2009; 1979; 1996; 1976;1977;1993).

Despite the important accent on relationships, this kind of genesis paradigm has recently been addressing other important issues, such as the personal 'history' of individuals and of their group, the cognitive style, and individual and systemic" characteristics." In 1976, Shadrikov defended his doctoral thesis on "Systemic approach in industrial training psychology" which laid the foundation for the school of thought in activity systemic genesis. Thereafter, his works on human action and abilities (articles, monographs, work-books etc.) were published in which he explicated the main theories and concepts of activity system genesis and psychological theory of human abilities. At the same time, he was working on the main theoretical issues of human psychology in the context of problems of modern education; this work reflects the growing interest that psychology has shown in the relational features of human behavior and human intellectual activity.

Shadrikov's scientific research on the development of methodological and theoretical psychological issues constitutes a part of the Russian contribution to psychology and education and reflects his diversified scientific activities on the national level. The results of such work were published in several monographs and methodological articles, scientific papers and speeches, which were presented at meetings of psychologists, international and national conferences on psychological issues, academic conferences and round tables, and also in numerous interviews with different educational leaders.

The most important works were presented in the authoritative academic periodical Psychological Journal published by the Academy of Sciences of the USSR (today known as the Russian Academy of Sciences), were approved for publication by the Institute of Psychology of the Academy of Sciences of the USSR (currently the Institute of Psychology of the RAS), were published by the publishing house "Nauka (Science)" and in the series "Psychologists of the Motherland" and "Psychological Achievements", received the official stamp of the Ministry of Education of the Russian Federation, and are widely recommended as workbooks for university students.

Below follows a brief description of his main works. Shadrikov's scientific opinion on addressing the problems of activity and abilities as independent fundamental problems of psychology has a dialectical interconnection. His point of view is represented in four main articles published in Psychological Journal - "Psychological Analysis of Activity as a System" (1980), "Problems of Occupational Abilities" (1982), "On Content of Terms 'Abilities' and 'Gifts'” (1983); "On Cognitive Abilities Structure" (1985) - in which he raises basic theoretical and methodological issues that help to form the content for a scientifically grounded program and predetermine, in many respects, the strategy of experimental systemic genesis research of human action and abilities.

Shadrikov's publication "Methodological Problems of Professional Training" published as part of multiauthor book Techniques of Engineering, Labor and Management Psychology (1981) is based on the analysis of current problems in applied psychology. It is very important from a methodological point of view for the development of higher education systems. Solutions to the outlined problems of psychology for professional training are set forth in another methodologically important work, "Introduction to Psychological Theory of Professional Training".

Shadrikov's monograph Problems of Systemic Genesis 
of Professional Activity (1982) recognized by the Institute of Psychology of the Academy of Sciences of the USSR makes an important contribution toward working out the methods of psychological analysis of activity. The first chapter of this work, "Systemic Approach to the Activity Research", presents the nature and principles of the systemic research of activity as a complex object of cognition. It contains the main operational terms for activity theory used in general psychology and was inserted into "Engineering Psychology Reader" (1991) in a condensed version in recognition of its scientific and didactic significance.

Another of Shadrikov's works entitled "Human Abilities" (1977) published in the series Psychologists of the Motherland specifies the system of his scientific views in the field of the psychology of abilities. However, general provisions of abilities theory developed by him reveal the nature, structure, determination of abilities development and ways of achieving selfcontrol over human abilities. They are interpreted by the scientist on the level of perceptual and spiritual abilities in the context of activity. Teaching and development in the process of mastering the activity are approved by experimental findings obtained by post-graduate students, postdoctoral students and fellow-psychologists. The monograph "Human Abilities" (1977) comprises a list of the most significant of Shadrikov's scientific works.

Shadrikov considers spiritual abilities as the object of psychological research in a separate monograph first published in 1998, which has gone through three editions. He analyzes, for the first time, the concept of spiritual abilities, shows the conversion of innate aptitudes into spiritual abilities, and considers issues related to the development of spiritual abilities relevant to the educational system. He also offers a new interpretation of pedagogical abilities as spiritual ones.

Three of Shadrikov's books were published under the imprimatur of the Ministry of Education of the Russian Federation. First, Cognitive Processes and Abilities in the Teaching Process: Workbook for Students of Pedagogical Institutes, (1990) a new type of workbook on general psychology for pre-service teachers written under the guidance of Shadrikov himself. This work combines informational, as well as practical and technical functions, and offers modern techniques to diagnose the level of cognitive abilities development. Second, Activity and Faculty Psychology: Workbook (1996), the first Russian integrative workbook on general psychology, educational psychology, labor and developmental psychology. The book went through two editions; the first entitled Activity and Abilities was published in 1994 as part of the program "Renewal of Education in the Humanities in Russia". The book described for the first time the relationship between the problems of individual labor activity, teaching activity and abilities through comprehension of psychological nature of teaching as a process of developing a system of psychological activity.

It is worth mentioning that the first Russian work in the form of a monograph revealed the psychological nature of a human - Human Origin: Student Training Manual (1999) - which went through two editions (the second one in 2001). Studying the process of human evolution, Shadrikov emphasizes special mechanisms of human survival, such as innate aptitudes and intelligence (individual potential) and shows that these are closely related to cognition and emotional intelligence. By studying social cognition and social neuroscience, he discovered many principles along which human social intelligence operates. He outlined the kinds of concepts people use to make sense of their social relations and asserts that expanded opportunities for social interaction enhance intelligence. This suggests that children require continuous opportunities for interpersonal experiences in order to develop a keen "inter-personal" psychology. Traditional schools do not facilitate interaction and complex social behavior; instead, children are treated as passive recipients who must be infused with lots of information. Schools today cultivate very few of the skills that are critical for survival in the world. As the development of the skills of "natural psychologist" in traditional schools is limited, graduates enter the job market handicapped to the point of being incapable of surviving on their own. The categories of spirituality and humanity have been introduced into the psychological sciences for the first time. Raising questions on spirituality as a specific human way of mental life, Shadrikov considers issues connected with the development and education of spiritual abilities. He states that the systemic genesis approach to the human origin and its relationship with morale is very important (2001).

Books such as Philosophy of Education and Educational Policy (1993) and Personalization of the Content of Education (1997) have methodological prominence and a strong practical connection with pedagogy. In the first book, addressing parents, teachers, education providers, students of pedagogical institutes and universities, Shadrikov points out that social intelligence is a distinctive perspective for education on the eve of the $21^{\text {st }}$ century. In the second work, the scientist points out that the content of education depends on the type of cognition, on pupils' intelligence, on the dominant mode of their thoughts and abilities. The teaching process should be based on individual education plans. Shadrikov thinks that teaching should be student-oriented and should advise and facilitate students to develop their practices, create development learning resources and reflect on their own practices. A deep analysis of universal and ethnocultural functions of education enabled Shadrikov 
to work out principles of individual curriculum and different content of education in a federal state.

Culture and ethnicity were viewed as separate from human behavior. Shadrikov treats ethnicity and culture as interdependent with social processes; in other words, ethnicity and culture are, at the same time, constructed within those interactions. Cultural features that define an ethnicity include family roles, work and recreational activities, shared values and concepts of achievement, shared expectations of behavior, and shared symbols, such as languages (1977a).

The study of learning processes, both cognitive and behavioral allowed Shadrikov to understand individual differences in intelligence, cognitive development, motivation, and self-regulation as well as their role in learning. Shadrikov thinks that the field of developmental education involves the study of memory, conceptual processes and individual differences in conceptualizing new strategies for learning.

In recent years, Shadrikov has published some important new monographs dedicated to the theoretical and methodological issues of psychology. In Shadrikov's Human Abilities and Intelligence (2004), Vladimir Dmitrievich reveals the nature of intelligence, offers a new intelligence model and outlines the ways of human intelligence development in the course of learning. Shadrikov also pays attention to the intellectual operations, which help to gain mental experience and are included under the human intellectual activity.

Shadrikov's book Intellectual Operations (2006) focuses on human intellectual operations as an independent category of psychological actions. He defines them, systemizes them and works out the possibilities of their development. Some kind of "periodic system of intellectual operations" specifies the development of operational characteristics of abilities: it becomes evident to what extent it is possible to "increase the number of extensively used actions and obtain a general skill in their performance". This book is important to the development of pedagogical psychology, psychology of abilities, psychology of thinking, psyche diagnostics, psychology of educational activity, etc.

The World of Human Interior Life (2006) was very important for addressing the methodological problems of modern psychology. The book was highly praised by the scientific community, which recognized it as a fundamental work that opens up prospects of psychology development and shows the ways of overcoming a permanent crisis and entering a new stage of development in methodological respect. A.V. Karpov notes that in this book he makes a significant step in the development of psychology, defines and implements a strategy of transfer from globally analytical stage of psychology development to a systemic stage where awareness of mental complexity entirety should be considered as an individual way of learning. (2006). A. V. Karpov compares Shadrikov's book with the book Fundamentals of General Psychology (2002) by S. L. Rubinsteinin, taking into account the coverage of psychological problems. The book demonstrates courage and constructiveness of the author's concept, which restores the idea of soul as a superior value of historical, philosophical and psychological thought. It also gives a strictly scientific reconstruction of a human. G. A. Suvorova similarly notes the importance of such a category as "the world of human interior life" in a system genesis interpretation for the purposes of advisory practice in education (Suvorova, 2006a; 2006b).

During the period 2001-2004, Shadrikov published a series of books, Introduction to Psychology, in which he gave a new life to the scientific facts and some theoretical and experimental studies that had become available to psychological science during the previous 50 years. He gave a new understanding of the fundamentals of psychology in his books: "Introduction to Psychology: Behavior. Motivation" (2001), "Introduction to Psychology: Emotions and Feelings" (2001), "Introduction to Psychology: Human Abilities" (2001, 2002), "Introduction to Psychology: the World of Human Interior Life" (2002), "Introduction to Psychology: Will and Volition Features" (2004), "Introduction to Psychology: Intelligence and Creativity" (2004), which were designated for scientists and experts in the field of psychology and humanities, as well as for the university students majoring in psychology and/or pedagogy. These works expand the idea of psychology both as a science and as an educational subject.

In his monograph Psychological Characteristics of a Normal Human Being, (2009b) Shadrikov describes the systemic genesis of personality traits. Having analyzed different methods of normal (mentally sane) human description in works of Russian and foreign psychologists, he points out ideological, theoretical and methodological issues which arise in the process of its (psychological) characteristics. Speaking about the abilities, motivational and emotional characteristics, Shadrikov demonstrates different personality traits that help to identify and describe aspects of personality. He identifies the relationship between different personalities and achievements in learning.

The most recent Shadrikov book, From Individual to Individuality: Introduction to Psychology (2009a) is of special note. In the Foreword to the book, A. L. Zhuravlev and M. A. Kholodnaya note that this is a dense and complex work and summarize it stating: “ [it] reflects almost all main branches and problems of a modern psychological science". They believe that the category of "a human" addressed by Shadrikov makes it possible to "include into the theoretical framework of his study mental (cognitive) process, psychological 
personality attributes, abilities and activities; and to join anthropological, neurophysiological, psychophysiological and psychological aspects of the problem of psyche; as well as to outline a way to study the individuality phenomenon and higher levels of mental development - intelligence, aptitude and faculty (Zhuravlev, Kholodnaya, 2009). The Shadrikov specifies three aspects of his work: evolution in history, in the subject of psychology and in the theory of activity (Shadrikov, 2009a).

\section{Systemic Genesis of Activity and Human Abilities}

The problem of activity is central in Shadrikov's scientific work (see 1994, 2007b, 1979, 1993). A deep and thorough examination of human activity allowed Shadrikov to create a psychological theory of systemic genesis of activity and human abilities which has been tested on models of two core human activities professional and teaching activity. Special conferences were devoted to the problems of systemic genesis. Different aspects of the systemic genesis approach in psychology have been discussed there. They revealed the solutions of a wide variety of issues in educational psychology (Nizhegorodtseva, 2003; Povarenkov, 2005; Povarenkov, 2007).

'Activity theory' is a term used in social science theory and research with roots drawing on the Soviet psychological activity theory pioneered by Lev Vygotsky, Alexei Leontyev and Sergei Rubinstein. These scholars understood human activities as complex, sociallysituated phenomena, and went beyond paradigms of reflexology (the teaching of V. Beekhterev) and physiology of higher nervous systems (the teaching of Ivan Pavlov), psychoanalysis and behaviorism. It became one of the major psychological approaches in Russia and was widely used in theoretical and applied psychology as well as in education and professional training.

Over a number of years the scientific situation around the problem of activity and activity approach in psychology was under discussion (Shadrikov, 1982; Abulkhanova-Slavskaya, Denisov, \& Chernyshev, 1981; Suvorova, 2006a; Suvorova, 2006b; Zhuravlev, Kholodnaya, 2009; Nizhegorodtseva, 2003; Povarenkov, 2005; Povarenkov, 2007; Bodrov, 1999; Davydov, 1996; Zhuravlev, 2005; Ilyasov, n.d.; Karpov, 1988; Karpov, 2004; Klimov, 1996; Leytes, Ravich-Shcherbo, 1985; Leontyev, 1977; Lomov, 1984). It is closely related to the problem of psyche. The psyche emerges and developed in history. Activity was the key analytical tool used by Leontyev in his historical analysis (1977). Activity was considered a vehicle for transmitting human experience from generation to generation. The structure of activity changed the structure of human interactions with the world. According to general activity theory, the human mind develops from historically contextualized, objectpractical activity (Leontyev, 1977). B. F. Lomov (1984) stresses the importance of working out the framework of categories and concepts of the psychological activity theory. V. V. Davydov (1996) raises a question of working out "extensive and detailed interdisciplinary activity theory of general psychology". The analysis proved that a wide use of the category 'activity' gave rise to different directions within this approach; this is necessary to describe possible ways of finding solutions for the most important theoretical problems of activity theory.

In activity theory, the individual is the principal object of study with importance also given to developmental, genetic principles and social interactions. However, activity theory is not focused exclusively on this question. Anokhin (1962) and Bernstein (1966) established self-regulation as a theoretical foundation for activity theory. According to the systemic-structural approach, activity is a complex, multidimensional system, requiring the use of systemic principles. One can extract from the same activity different structures as independent objects of study, depending on the purpose of study.

Shadrikov addresses problems arising from this systemic approach; he was primarily interested in the frame of a systemic genesis approach. Firstly it should be noted that the titles of Shadrikov's works on psychology of activity directly address the problems of systemic genesis of activity: "Psychological Analysis of Activity: System Genesis Approach" (1979), "Psychological Analysis of Activity as a System" (1980), "Problems of System Genesis of Professional Activity" (2007 b), "Human Activity and Abilities" (Shadrikov, 1994), "Activity Psychology and Human Abilities" (1996).

Shadrikov highlights the key points in his method: activity - systemic approach to the activity research - system genesis of activity - process, problems and laws of construction of psychological activity system - ways of improvement of activity efficiency. He particularizes the content of psychological analysis of activity both as an independent subject of study and as an explanatory principle. He also provides a paradigm of psychological activity analysis, points out the methodological principles and theoretical procedures of the system analysis of activity as a complex object of cognition, and seeks to settle a matter on activity structure and its mechanisms. It is worth noting that Shadrikov devotes much attention to formulating a clear conceptual framework in all his theories, such as theory of personality system genesis, psychological theory of abilities, evolutional personality concept, individualization concept of content of education, concept of personality experience in the process of professional and subject training, concept of educational abilities as spiritual ones, etc. 
Shadrikov also helped define the basic terms of psychological activity: activity, activity goal, activity result, activity characteristics, activity effectiveness parameters, goal parameters, work method, regulatory approved work method, individual work method, individual work style, structure, function (element, structure, system), system, structure and system elements, structure and system components, dynamic system, activity structure psychological activity structure, functional psychological activity system, psychological activity system and system genesis. A consideration of the activity as "human activity type expressed in hormic transformation of a natural and social reality" pervades all his studies.

In the psychological analysis of activity, Shadrikov identifies, for the first time ever, such terms as "activity structure", "psychological activity structure", and "psychological activity system". Shadrikov also distinguishes the nature of two separate concepts, "system" and "structure", in psychological activity analysis. The system is defined as a "structure which is considered in reference to its definitive function" and requires the use of systemic principles. As far as system is concerned, it is noted that the same result can be reached by different systems and in one and the same structure the same elements can be distributed among different systems according to the designated use. In Shadrikov's opinion, the system always has a functional aspect; therefore, such terms as "system" and "functional system" act as synonyms.

"Psychological activity system" as a basic concept of Shadrikov's systemic genesis theory subsequently became a methodological term. K. A. AbulkhanovaSlavskaya notes this fact $(1979,2007)$ and states that Shadrikov raises methodological questions in the process of addressing a problem of activity through a clear and complete highlighting of psychological aspect of its analysis. He introduces a new concept of psychological activity system and outlines components and levels of its systemic genesis analysis. Abulkhanova shows that the author of activity system genesis theory traces the relationship between psychological activity structure and real social activity by highlighting the subjective result of activity, comparing it with a social one, and integrating these two different activity realities through a personality (Abulkhanova-Slavskaya, Denisov, \& Chernyshev, 1981; Abulkhanova, 2007).

In the systemic genesis approach, cognition is understood as a process and as a system of actions or other functional information processing units. Thus cognition incorporates both structure and system. Shadrikov's method entails a plan of activity within which all components of activity - goals conditions, tools, etc. - are integrated. He maintains that the psychological character and subject of psychological study of activity is "a functional psychological system of activity which is formed on the basis of qualities of an individual accomplishes the activity goal" (1996, p. 287).

Having discovered the specific features of cognition using the systemic approach, Shadrikov then outlined the outstanding features and main directions of realization of this approach in the process of activity research by pointing out the conditions for a uniform understanding of systemic research results. Shadrikov states the object, subject and tasks, then specifies the base lines of psychological activity research, and finally offers a general theoretical construct (model) realizing the psycho-physical unity approach in his investigation.

To summarize, in his works Shadrikov specifies: (1) the change of the objective world and the related change in the process of goal-directed activity of a personality; (2) the mechanism of a psychic activity regulation; (3) the change of a human in the process of activity; (4) the impact of activity on human nature (1994, p. 10). In the process of analyzing systemic genesis theory, Shadrikov has created an ideal model of psychological activity system and its theoretical construct. He has also outlined certain solutions in relation to the detailed tasks of psychological activity study using this model. Noting that in the process of developing the architecture of psychological activity system, he based his work on the framework of a functional physiological system created by P. K. Anokhin, Shadrikov emphasizes that the structural elements of a psychological activity system have another content; this distinct content is signaled and described in the psychological theory of activity systemic genesis (1994; 2007b; 1979; 1996). Thus Shadrikov found the answer to the question of a universal psychological mechanism of activity.

Activity is performed through a functional system, which at the level of psychological analysis acts as a psychological activity system. For this reason it is possible to carry out the activity analysis and describe its separate components. Activity can be described by taking into account both developmental and functional mechanisms. However the author of the systemic genesis theory specifies that each activity type has different content of psychological activity system, mechanisms of development, relationship between the components of psychological activity system, connection between the compositional analysis and efficiency of psychological activity system, and system-forming factors of activity at the various stages of its mastering. He proves that the activity development indicators increase due to the development of a complete psychological activity system, with integrity of its various components (motivational, informational, programming, and controlling) (Shadrikov, 2007b).

In his works, Shadrikov considers the close relationship of professional and teaching activities and the possibility of applying the objective laws of activity 
systemic genesis to the teaching activity (1994; 1996). He advances the notion that the structure of activity and behavior determine the human inner world (2006; 2009a).

The genesis approach examines how the cultural means used by society at different stages of historical development influence cognitive and psychic processes. The historical development of human culture and psyche allows for a deeper grasp of activity as a whole. Shadrikov states that a man and his psyche are formed and manifested in the process of activity and, therefore, they can be studied firstly through manifestation in one or another type of activity. In some of his works, Shadrikov reports on human development in the process of activity. In a series of his studies, he demonstrates that the development of psychic qualities in the process of activity is made through the development of operating mechanisms of such qualities; under the influence of activity requirements, the operating mechanisms of psychic qualities are being transformed. $\mathrm{He}$ calls this process a process of conversion of operating mechanisms into operative ones. He believes that this is the essence of transfer from psychic qualities to the actively important (professionally and educationally) ones. Taking into account the systemic genesis principles, Shadrikov reveals the psychological mechanism of qualitative formations in the personality ontogeny process. He writes:

"This process is marked by availability of stages and it splits the growth of some qualities... The most formations act as functional systems. It is the functional system that resolves contradictions between the limit of essential personal qualities and the variety of activity and behavior forms. The individual qualities can be manifested at the same time through the activity style and behavior individuality. It is in the functional system that inheritable qualities and qualities to be developed, as well as qualities to be educated and acquired act as a whole and determine activity and behavior" (1993).

He further notes that development process appears both with respect to certain essential individual qualities and in the process of functional systems that realize some types of activity and behavior.

The system consideration of activity and its nature as a multilevel construction are revealed in the system genesis activity theory through a mixed-level analysis: person-motivational, component-objective, structurefunctional, informational, psycho-physiological and individual-psychological. Shadrikov estimated the combination of all specified levels and gave a systemic concept of activity, which he believed should be regarded as a multilevel system. Taking this into account, he developed strategies, methods, and experimental procedures for each level of activity (2007a).

Shadrikov tackled the problem of the relation between abilities and activity. Consideration of general and specific abilities on the basis of psychological analysis of activity allowed him to differentiate the development of professional abilities from general abilities. He offered general principles of abilities diagnostics and validated the abilities diagnostics method, which received the name of 'activity development method'. Shadrikov motivated his pupils who continued to work out different modifications of this method (Suvorova, 2007).

Shadrikov stated the general principles of systemic approach to the study of complex objects of cognition with two kinds of systemic knowledge (mono and polysystem focusing). He set specific scientific-method requirements to the organization procedure of a system research of activity as a complex object of cognition. He also considered the relationship between cognition, abilities and activity results, and compared scientific cognition levels and scientific thinking methods.

B. F. Lomov qualifies the systemic genesis laws specified by Shadrikov as psychological laws that form the "mechanism" of psychical phenomena (1984, p. 112). A. V. Karpov accentuates that the concept of activity systemic genesis is a unity of system, genetic and psychological study of activity (1988, p. 11). V. A. Bodrov notes that Shadrikov's systemic genesis concept offers a methodological base for psychological study of professional activity, reflects systemic principles of mental alertness, and its variability; this concept helps to work with " professional activity" (1999, p. 644).

The founder of the activity system genesis theory uses the term "functional system", which was first studied by P. K. Anokhin and A. R. Luriya, yet Shadrikov fully demonstrates the possibilities of its use in the process of working with the terms "abilities" and "gifts". Shadrikov considers the role of certain abilities in the activity structure and offers his own point of view. Shadrikov specifies the fundamental hypothesis in tackling the problem of abilities structure. It is based on the principle that this structure is uniform for all abilities and similar to the activity structure, i.e. while there are multiple abilities you have a single and uniform activity structure which is repeated in structures of individual abilities. He points out that ontologically this uniform structure is realized through the brain entirely as a mental organ and is functionally determined by activity goal and motivation. In the abilities theory, Shadrikov allows for the fact that abilities are functional systemic features which fulfill some psychical functions and psychical functions are activity forms and can be characterized as functional activity systems.

The following problems are considered to be most 
important by Shadrikov: the determination of the position of category of abilities in the system of base psychological terms and concepts; the determination of human abilities in three dimensions - individual, actor and personality; the detection of abilities position in the psychic structure; revealing the relationship between general and specific abilities; establishing the relationship between abilities and mental processes; detecting the mechanism of abilities development: mastering intellectual operations and developing general skills; classifying the abilities according to their psychical functions; finding the ways of abilities development through activity: integration of certain abilities in the activity system and adaption of abilities to the object world and activity requirements etc.; and finally, interpreting an abilities problem as mental development problem (Shadrikov, 1998; 2007a; 2009a; 1993).

Shadrikov proves and elaborates that intelligence development is made through mastering intellectual operations, developing mental skills, gaining mental experience and introduction into the intellectual activity of the human's inner world (Shadrikov, 2007a).

An analysis of Shadrikov's views on evolution and assessment of his studies in the field of psychology have been carried out by N. S. Leytes and I. V. RavichShcherbo, D. B. Bogoyavlenskaya and I. V. Dubrovina. N. S. Leytes and I. V. Ravich-Shcherbo made comments on B. M. Teplov's publication on abilities and gifts (1985, p. 313) They noted that gift as a synthetic concept characterizing the abilities is considered in his theory as a systemic demonstration of abilities. However, Shadrikov gives a further detailed analysis of this problem in his article "On Content of Terms "Abilities" and "Gifts" (1983).

D. B. Bogoyavlenskaya points out that Shadrikov's abilities theory reveals a new approach to the problem of nature and the relationship between general and specific abilities, offering a holistic comprehension of gifts. It allowed those who studied the operational gifts concept to work out a general position for leading Russian specialists. They observed giftedness as a system quality and specified principles and methods for the development of gifted children (Bogoyavlenskaya, 2003).

Shadrikov's work was presented at the II International research and practice conference "Operational Concept of Gifts - to the Educational Practice" (Dubrovina, 2004). The book was devoted to cognitive abilities. This conference pointed out the existence of Shadrikov's school of thought with its own clear-cut and articulated policy, scientific opinion. The work that has been done over the course of many years on the abilities problem comprises a deep theoretical body of work, which should be considered as a unique event in our academic community. Shadrikov has made a great contribution to the theoretical understanding of abilities problem by studying the nature of human abilities, their structure and development in the context of a coherent human being. He also formulated an approach to abilities as personal manifestations which are always expressed through a level of skills in any type of activity - teaching, cognitive and professional activity. Placing special emphasis on the complexity of theoretical aspects of abilities, he treated the individual as an actor and personality, and paid special attention to the analysis of the process and ways of abilities development.

The importance of key issues of activity psychology in the elaboration of abilities problems researched by Shadrikov has been stressed by A. K. Bolotova (1977). It should be noted that among topical issues of Shadrikov's psychological theory of abilities which are essential to the development of consultative function of a psychologist in the field of education are the following issues: working at defining the terms "giftsabilities-psychic activity-activity"; raising a question on development of abilities in a variety of conditions of human vital activity; pointing out the importance of experimental study of mechanisms of human abilities development; operating mechanisms of pupils' development of cognitive abilities; determination of the key role of cognitive actions and tasks in their analysis (Suvorova, 2006a; Suvorova, 2004).

\section{Future Development of System Genesis Approach in Psychology}

While not all ideas are claimed in the "intelligent card" of the systemic genesis approach, Shadrikov's contribution can be summarized in three essential points: (1) he developed systemic genesis approach in the process of working at methodological and theoretical problems of psychology; (2) he defined strategies of the systemic genesis approach in the process of studying psyche, activity, abilities, human's inner world and human individuality; (3) he drew weighty conclusions in methodological respect which concern contemporary problems of theory and practice of psychology in the field of education.

Shadrikov's works are very important for specifying the content and strategies of pedagogical psychology as an educational subject in the system of training teachers and psychologists. Any person, his/her activity, activities, morals, spirituality, ability to understand, recognize and transform the external and inner world are placed at the center of educational and developmental psychology.

Methods of the systemic genesis approach are applied in the process of investigation of personal integral qualities and abilities, and metacognitive processes (Karpov, 2004). Children's psychological 
readiness for school is an individual manifestation of general/universal human quality - readiness for actions (Nizhegorodtseva, Shadrikov, 2004) etc.

Studies on systemic genesis are fundamental for the development of expert activities of a psychologist in mass media and consulting in the field of education (Suvorova, 2006a). They enable to enter and carry on a multifunctional and multilevel dialogue. The problems they cover are: mental development of a man; his intelligent education both in town and country; selfevolution on the level of personality and individuality; operation of psychological laws; existential psychology and life scenarios; child-parent relationships in new cultural-historical contexts; propaganda of psychological knowledge of spiritual development and growth of a human, etc.

The theoretical and practical role of systemic genesis concepts in psychology of professional training for highly qualified teachers was embodied in a new professional teaching standard developed on the basis of Shadrikov's model of a functional psychological activity system (Kuzminov, Matrosov, \& Shadrikov, 2006). Based on the systemic genesis activity theory, a psychological analysis of teaching activities was carried out. Specific theoretical data on teacher's activities, the functional tasks, and the problem of teacher as a subject of teaching activity were generalized. The content of a professional teacher's competency was also defined. The basic competences of a teacher are specified according to the main components of a functional system of his activity, assuring success at work. The psychological framework was established for specifying the content of professional training programs for contemporary teachers. The combination of activity, systemic and competence approach in professional teaching standards defines the strategic areas for the development of psychological innovations in the field of education.

The expansion of reflexive bases of the systemic genesis approach as a new paradigm of psychological science in education can be further developed the coherent research program on activity systemic genesis and human abilities makes such expanded research possible. The study of the problems of socialization and professional self-realization, which are needed in practice, is still a work in progress.

\section{References}

Abulkhanova, K. A. (2007). Recenzija na knigu V. D. Shadrikova «Mir vnutrennej zhizni cheloveka» [Review on the V. D. Shadrikov book "Inward man"]. Psychological Journal, 28(2), 125-127.

Abulkhanova-Slavskaya, K. A., Denisov, V. A.,
Chernyshev, A. P. (1981). Recenzija na knigu V. D. Shadrikova "Psihologicheskij analiz dejatel'nosti" [Review on V. D. Shadrikov's book "Psychological analysis of activity"]. Psychological Journal, 2(4), 165-166.

Bodrov, V. A. (1999). Psihologija professional'noj prigodnosti [Psychology of professional activity]. In V. N. Druzhinin (Ed.), Sovremennaja psihologija. Moscow, Russia: INFRA-M.

Bogoyavlenskaya, D. B. (2003). National approaches to understanding of the nature of abilities and gifts. In Nizhegorodtseva, N. V. (Ed.), Sistemogenez uchebnoj i professional'noj dejatel'nosti (pp. 23-26). Yaroslavl, Russia: YSPU.

Bolotova, A. K. (1977). Novyj vzgljad na problemu sposobnostej [New view on the abilities problem]. Voprosy Psihologii, 2.

Davydov, V. V. (1996). Problema dejatel'nosti v filosofii i psihologi [Problem of activity in philosophy and psychology]. In Teorija razvivajushhego obuchenija (pp. 10-13). Moscow, Russia: INTOR.

Dubrovina, I. V. (2004). Recenzija akademika RAO I. V. Dubrovinoj na doklad V. D. Shadrikova "Razvitie poznavatel'nyh sposobnostej" [Review of the member of the Russian Academy of education on the report by V. D. Shadrikov "Development of cognitive abilities"]. Odarennyj Rebenok, 5, 13-16.

Ilyasov, I. I. (n.d.). O problemnyh tochkah dejatel'nostnogo podhoda [On problem points of the activity approach]. In N. F. Talyzina (Ed.), Materialy metodologicheskogo seminara po problemam dejatel'nostnogo podhoda $v$ psihologii. Retrieved from http: / / www.psy.msu.ru / science / seminars / index.html/

Karpov, A. V. (1988). Psihologicheskij analiz trudovoj dejatel'nosti [Psychological analysis of labor activity]. Yaroslavl, Russia: YaSU.

Karpov, A. V. (2004). Psihologija refleksivnyh mehanizmov dejatel'nosti [Psychology of reflexive mechanisms of activity]. Moscow, Russia: Publishing house of the Institute of Psychology of the Russian Academy of Sciences.

Karpov, A.V. (2006). Kniga o vnutrennem mire cheloveka [The book on the inward man]. Voprosy Psihologii, 5, 177-179.

Klimov, E. A. (1996). Psihologija professionala. Psihologi Otechestva [Psychology of a professional. Psychologists of the Motherland]. Moscow, Russia: Voronezh.

Kuzminov, Ya.I., Matrosov, V.L., \& Shadrikov, V.D.(Eds.). (2006). Professional'nyj standart pedagogicheskoj dejatel'nosti. Razrabotan po gosudarstvennomu kontraktu №P 242 ot 11.09.2006 [Professional standard of teaching activities. Developed under State contract \#P 242 dated 11.09.2006]. Moscow, Russia: HSE. 
Leontyev, A. N. (1977). Dejatel'nost'. Soznanie. Lichnost' [Activity. Consciousness. Personality]. Moscow, Russia: Politizdat.

Leytes, N.S., Ravich-Shcherbo, I.V.(1985).Kommentarii: Sposobnosti i odarennost' [Comments: Abilities and gifts]. In B. M. Teplov. Selected works (Vol. 1). Moscow, Russia: Pedagogica.

Lomov, B. F. (1984). Metodologicheskie i teoreticheskie problemy psihologii [Methodological and theoretical problems of psychology]. Moscow, Russia: Nauka.

Nizhegorodtseva, N. V. (Ed.). (2003). Problemy sistemogeneza uchebnoj i professional'noj dejatel'nosti. Materialy Rossijskoj nauchno-prakticheskoj konferencii [Problems of system genesis of teaching and professional activity. Materials of Russian research and practice conference]. Yaroslavl, Russia: Avers-Press.

Nizhegorodtseva, N. V., Shadrikov, V. D. (Eds.). (2004). Sistemogeneticheskij analiz gotovnosti $k$ obucheniju [System genesis analysis of readiness to teaching]. Yaroslavl, Russia: Avers-Press.

Povarenkov, Yu. P. (Ed.). (2007). Sistemogenez uchebnoj $i$ professional'noj dejatel'nosti: Materialy tret'ej vserossijskoj nauchno-prakticheskoj konferencii [System genesis of teaching and professional activity: Materials of the third All-Russian research and practice conference]. Yaroslavl, Russia: Kantsler.

Povarenkov, Yu. P. (Ed.). (2005). Sistemogenez uchebnoj $i$ professional'noj dejatel'nosti: Materialy vtoroj vserossijskoj nauchno-prakticheskoj konferencii [System genesis of teaching and professional activity: Materials of the second All-Russian research and practice conference]. Yaroslavl, Russia: Kantsler.

Shadrikov, V. D. (1976). Psihologija proizvodstvennogo obuchenija (Sistemnyj podhod) [Psychology of industrial training (System approach)]. Yaroslavl, USSR: YaSU.

Shadrikov, V. D. (1977a). Individualizacija soderzhanija obrazovanija [Personalization of the content of education]. Moscow, USSR: Ventana-Graph.

Shadrikov, V. D. (1977b). Sposobnosti cheloveka [Human abilities]. Moscow, USSR: Publishing House Institute of Practical Psychology.

Shadrikov, V. D. (1979). Psihologicheskij analiz dejatel'nosti. Sistemogeneticheskij podhod [Psychological analysis of activity. System genesis approach]. Yaroslavl, USSR: YaSPI.

Shadrikov, V. D. (1993). Filosofija obrazovanija $i$ obrazovatel'nye politiki [Philosophy of education and educational policies]. Moscow, Russia: Logos.

Shadrikov, V. D. (1994). Dejatel'nost' $i$ sposobnosti cheloveka [Human activity and abilities]. Moscow, Russia: Logos.

Shadrikov, V. D. (1996). Psihologija dejatel'nosti $i$ sposobnosti cheloveka [Activity psychology and human abilities]. Moscow, Russia: Logos.

Shadrikov, V. D. (1998). Duhovnye sposobnosti [Spiritual abilities]. Moscow, Russia: Magister.

Shadrikov, V. D. (2001). Proishozhdenie chelovechnosti [Humanity origin]. Moscow, Russia: Logos.

Shadrikov, V. D. (2006). Mir vnutrennej zhizni cheloveka [Human inner world]. Moscow, Russia: Logos.

Shadrikov, V. D. (2007a). Mental'noe razvitie cheloveka [Mental development]. Moscow, Russia: Logos.

Shadrikov, V. D. (2007b). Problemy sistemogeneza professional'noj dejatel'nosti [Problems of system genesis of professional activity]. Moscow, Russia: Nauka.

Shadrikov, V. D. (2009a). Ot individa $k$ individual'nosti: Vvedenie $v$ psihologiju [From individual to individuality: Introduction into psychology]. Moscow, Russia: Publishing house Institute of Psychology of the Russian Academy of Sciences.

Shadrikov, V. D. (2009b). Psihologicheskaja harakteristika normal'nogo cheloveka, ili poznaj samogo sebja [Psychological characteristics of a normal human being, or know yourself]. Moscow, Russia: Universitetskaya Kniga; Logos.

Suvorova, G. A. (2004). Osnovy konsul'tativnoj raboty po razvitiju odarennosti [Fundamentals of the consultation work on gifts development]. Odarennyj Rebenok, 5, 24-26.

Suvorova, G. A. (2006a). Dejatel'nostnyj podhod $k$ psihologicheskomu konsul'tirovaniju $v$ obrazovanii: Sistemogeneticheskaja paradigma [Activity approach to psychological counseling in education: System genesis paradigm]. Moscow, Russia: Prometey.

Suvorova, G. A. (2006b). Mir vnutrennej zhizni cheloveka kak predmet dialoga subjektov psihologicheskogo konsul'tirovanija $v$ obrazovanii [The human inner world as subject matter of a dialogue between subjects of psychological counseling in education]. In Materialy Vserossijskoj konferencii Psihologija individual'nosti (pp. 490-493). Moscow, Russia: Logos.

Suvorova, G. A. (2007). Sistemogenez dejatel'nosti $i$ sposobnostej cheloveka kak napravlenie issledovanij $v$ nauchnoj shkole Vladimira Dmitrievicha Shadrikova [System genesis of human activity and abilities as a line of research in Shadrikov's school of thought]. Moscow, Russia: Festschrift.

Zhuravlev, A. L. (2005). Psihologija sovmestnoj dejatel'nosti [Psychology of joint activities]. Moscow, Russia: Publishing house of the Institute of Psychology of the Russian Academy of Sciences.

Zhuravlev, A. L., Kholodnaya, M. A. (2009). Predislovie [Foreword]. In V. D. Shadrikov, From individual to individuality: Introduction to psychology (pp. 1116). Moscow, Russia: Publishing house Institute of Psychology of the Russian Academy of Sciences. 